症例

脂肪肉腫様の分化を示した $2 \mathrm{~cm}$ 以下の乳腺悪性葉状腫瘍の 1 例

国際親善総合病院外科

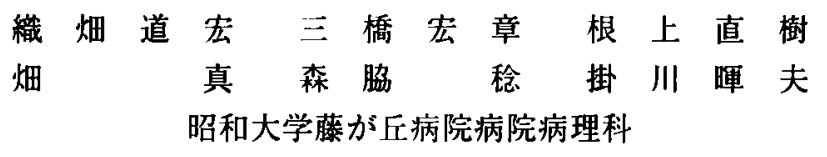

楯玄秀 光 谷 俊 幸

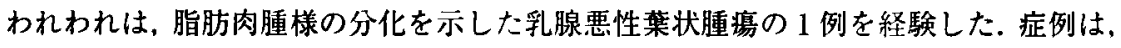
53 嵅女性. 1996 年 8 月無痛性の右乳房腫瘤に気づき当院受診, 右 $\mathrm{CD}$ 領域に径 $1.5 \mathrm{~cm}$ の境界明瞭な硬い腫瘤を認めた，超音波検査では，腫怚は辺縁平滑で緱横比が低く，内 部が低エコーと高エコーのモザイクをなし外側陰影を伴っていた. マンモグラフィでは 腫場は境界明瞭で透明帯を認めた。摘出標本より，脂肪肉腫様の分化を示した乳腺悪性 葉状腫場と診断, 非定型的乳房切除術（Bt+Ax）を施行した．腋窝りンパ節転移は認め なかった. 放射線療法や化学療法を行ってはいないが, 術後 1 年 10 カ月たった現在も再 発を認めていない.

索引用語：乳腺, 脂肪肉腫, 悪性葉状腫愓

\section{緒言}

乳腺の肉腫は，乳腺の原発性墨性腫場中 $1 \%$ 以下と 少なく, 脂肪肉腫はそのおよそ 4 分の1を占めている にすぎない．今回, 触診および画像診断上. 良性腫瘍 との籍別が困難であった脂肪肉腫粎の分化を示した乳 腺悪性葉状腫場の 1 例を経験したので, 若干の文献的 考察を加えて報告する。

\section{症 例}

患者： 53 藏，女性.

主訴：右乳房腫瘤.

既往歴：特記すべきことなし.

家族歴：妹が乳癌.

現病歴：1996年 8 月 12 日右乳房腫瘤に気づき, 8 月 26 日当院を受診した.

来院時現症: 身長 $156 \mathrm{~cm}$, 体重 $48 \mathrm{~kg}$, 右乳房外側 ( $\mathrm{CD}$ 領域)に無痛性の径 $1.5 \mathrm{~cm}$ の境界明瞭な硬い腫瘤 を認めた。

乳腺超音波検查: 右 $\mathrm{CD}$ 領域に, 辺縁平滑, 境界工 コーは線状で, 縦横比 0.46 と小さい楕円形の腫場 $(0.58$ $\times 1.25 \mathrm{~cm}$ )を認め, 内部は低エコーと高エコーのモザ イクを示し, 後方エコーはやや増強し, 外側陰影を伴っ

1998 年 9 月 1 日受付 1998 年 12 月 8 日探用
ていた（図 1).

マンモグラフィ：右乳腺 CD 領域に辺縁平滑で境界 明瞭な腫堭 $(1.3 \times 1.1 \mathrm{~cm})$ を認め, 透明带 (Halo-sign) も一部に認めた（図 2).

臨床経過：画像診断上, 良性腫瘍と診断し, 1996 年 9 月 13 日, 腫瘍摘出術を施行した.

摘出した腫瘍は, $1.2 \times 1.0 \times 0.6 \mathrm{~cm}$ で表面平滑で境界 明瞭であった（図 3 )。

摘出標本の病理組㳦学的所見: 腫瘍は被膜におおわ れ周囲と明瞭に区別されていた. クロマチンに富む異 型核を有する脂肪芽細胞が認められ, 脂肪肉腫と診断 した（图 4)。腫瘍は成熟脂肪細胞に脂肪芽細胞が散見 される高分化型脂肪肉腫（well differentiated type）を 主体とし，そこに多核巨細胞を含むさまざまな形の腫 場細胞よりなる多形型脂肪肉腫 (phleomorphic type）の部分が混在していた。また被膜におおわれた 腫瘍内に增生を示す上皮成分が認められた。

免疫組織化学的染色において, 脂肪芽細胞は, 上皮 性マーカーのケラチン (KL-1.Z 622) や EMA (epithelial membrane antigen) に陰性, 組織球系マーカーの KP-1, $\alpha$ 1-アンチトリプシンに陰性, 非上皮性のマー カーのVimentin に(土)で, S-100に一部(土)であっ た. 


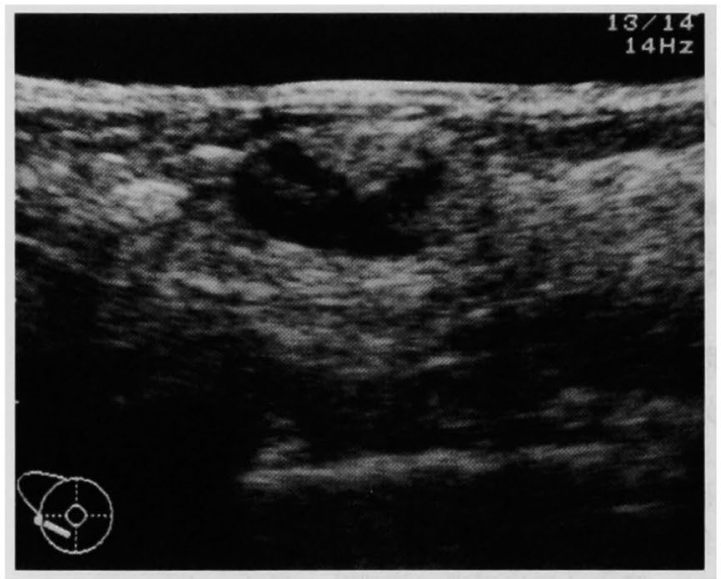

困 1 乳腺超音波検查: 辺縁平滑, 境界エコーが線状, 外側陰影を伴う紂横比の小さな腫境を認め。内部は 低エコーと高エコーのモザイクを示していた.

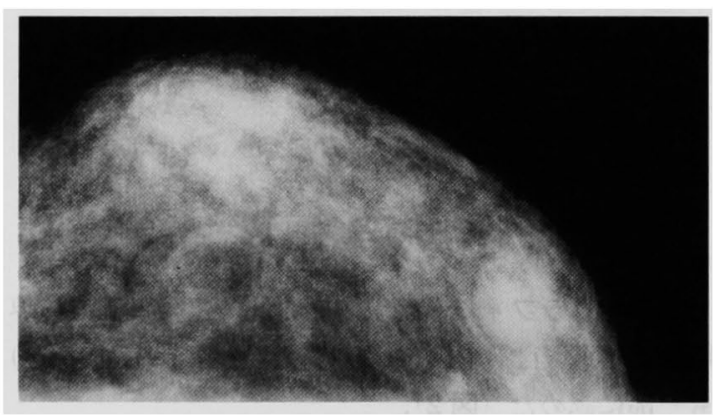

図 2 マンモグラフィ検査：辺縁平滑で境界明暸な透 明帯を伴う腫瘤を認めた。

エストロゲンレセブターとプロゲステロンレセプ ターの定量検査はともに陽性であったが, 免疫組織化 学的染色では,これらのホルモンレセフターは上皮細 胞にのみ認められ，脂肪芽細胞には認めなかった。

以上から脂肪肉腫と診断したが, 腫瘍内に增生を示 す上皮成分を認めたことから乳癌取扱い規約の分類上 まず葉状腫場に分類し、組織型として脂肪肉腫とした.

1996 年 10 月 28 日, 腫瘍近傍の大胸筋の部分切除を 加之非定型的乳房切除術 $(\mathrm{Bt}+\mathrm{Ax})$ を施行した。

手術標本の病理組識所見：手術標本の乳腺には腫場 細胞の残存を認めず，腋盆りンパ節転移も認めなかっ た.

術後, 放射線療法や化学療法やホルモン療法は行っ てはいないが,術後 1 年 10 カ月たった現在も再発を認 めていない。

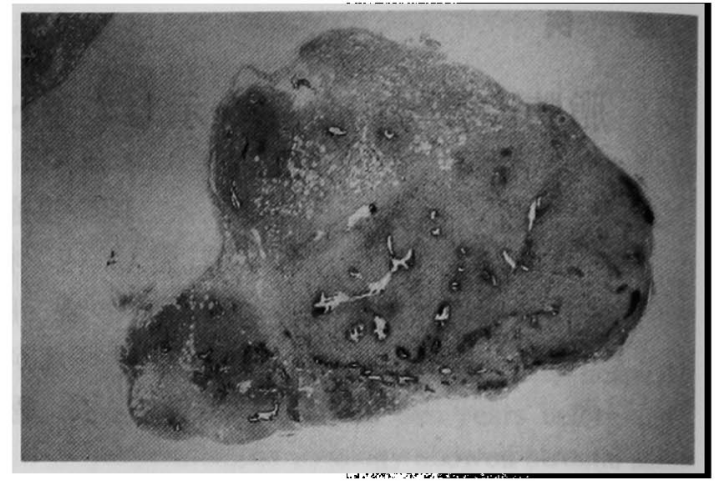

図 3 摘出堙理標本のルーベ像：腫場は, 被膜におお われ，腫瘍内には乳腺上皮成分を認めた。

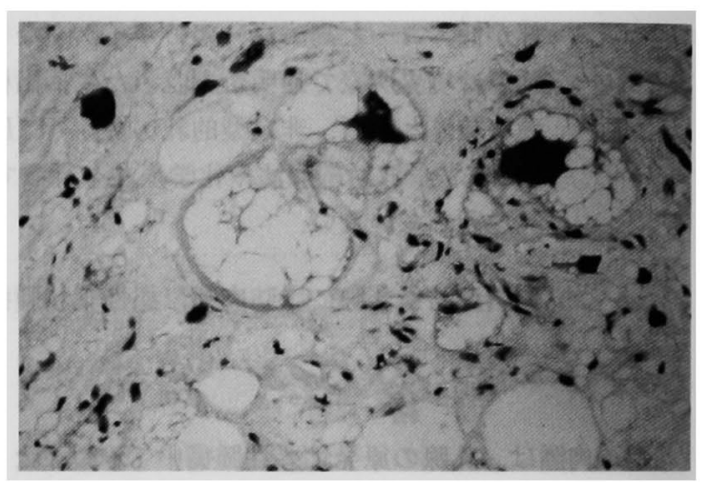

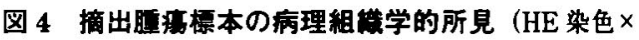
400）：クロマチンに富む異型核を有する脂肪芽細胞 が認められ，脂肪肉腫と診断した。

\section{考察}

乳腺の肉腫は, 乳腺の原発性悪性腫瘍中 $1 \%$ 以下と 少なく、脂肪肉腫はそのおよそ 4 分の 1 を占めるにす ぎない".

自験例を，葉状腫瘍に発生した脂肪肉腫と分類し， 文献的に考察を行った.

検索し得た本邦の脂肪肉腫の報告例は自験例を含め 15 例であっだ ー 15)．その内, 葉状腫瘍に発生した症例 は自験例を含め 2 例であった する症例は 2 例(67), 葉状腫瘍と関連のない症例は2 例(14)15)であった。

性別は記載のない 1 例を除きすべて女性で，平均年 齛は，49 歳であった。

臨床症状は乳房腫瘤が 12 例, 乳房腫大が 1 例であっ た. その特徽は, 腫瘤は無痛性 $(9$ 例 $/ 9$ 例) であるこ と, 病悩期間が 1 年以上の 5 例は，全例急激な腫㽷の 増大を主訴とした症例であった。一方病恼期間が 
月以内の 8 例では急激な腫㿔の增大は認めなかった。

腫瘤の部位は右 5 例, 左 8 例であった。

手術は, 定型的乳房切除術 5 例, 非定型的乳房切除 術 5 例, 单純乳房切除術 1 例, 腫場切除術 2 例であっ た。リンバ節郭清をした 8 例すべてにリンパ節転移を 認めなかった。

腫湯径は $10 \mathrm{~cm}$ を越える症例が 5 例, $5.1 \sim 1.0 \mathrm{~cm}$ の症例は 1 例, $2.1 \sim 5.0 \mathrm{~cm}$ の症例は 6 例, $2.0 \mathrm{~cm}$ 以下 の症例は 2 例であった。

組織型は高分化型 4 例, 粘液型 8 例, 多形型 2 例で あった。

予後の記載のある症例で死亡した症例は 2 例で, 死 因は悪液質 (3 年 9 カ月) と心不全 (13 日) であった.

欧米の報告によると, Austin ら ${ }^{16}$ は，葉状腫凒と関 連のない純粋な脂肪肉腫と葉状腫場に発生した脂肪肉 腫とに分けて 20 例の脂肪肉腫について報告している.

性別では, 純粋な脂肪肉腫 13 例中に男性を 2 例認め たが，葉状腫愓に発生したものは 7 例すべて女性で あった．また平均年齱はともに 47〜 48 歳であった.

部位は，すべて片側で，純粋なものは右に 7 例と左 に6例，葉状腫瘍に発生したものは右に 5 例と左に 2 例であった.

症状はともに，しばしば痛みを伴い増大する腫瘍の 触知であった。

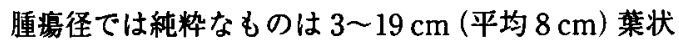
腫湟に発生したものは 4 23 cm（平均 $11 \mathrm{~cm}$ ) であっ た.

組織型は純粋なものは高分化型 5 例, 粘液型 4 例, 多形 4 例で葉状腫瘍に発生したものは高分化型 2 例, 多形型 5 例であった。

術式な純粋なものは非定型的乳房切除術 6 例, 単純 乳房切除術 3 例, 局所切除術 4 例で葉状腫湯に発生し たものは非定型的乳房切除術 1 例, 単純乳房切除術 3 例，局所切除術 3 例であった.

腋窩リンバ節転移はすべて認めなかった。ただし例 外的に脂肪肉腫が腋䆚リンパ節転移を来した $2 つ の$ 報 告があるとしている.

再発は純粋なものは 13 例中 3 例, 葉状腫瘍に発生し たものは 7 例中 1 例で, 全体として 20 例中 4 例（20 \%)であった. 再発を来たした症例はすべて多形型で 浸潤性の発育のものであった。一方高分化型で男性例 で圧排性の発育する症例には再発を認めなかった。た だし文献的には高分化型で局所再発した例もあるとし ている. 再発はすべて初回診断後 1 年以内に認められ
たという。

Pollard ${ }^{11}$ は, 脂肪肉腫 6 例中 3 例 $(50 \%)$ が, Christensen $5^{17}$ は, 脂肪肉腫 7 例中 3 例 $(43 \%)$ が再発死し たとしている.

乳腺の肉腫の手術術式は, Pollard ら ${ }^{1}$ によれば, 乳腺 部分切除術や単純乳房切除術では局所再発が高率だが （それぞれ 6 例中 4 例 $(67 \%) ， 13$ 例中 7 例 $(54 \%)$ )， 非定型的乳房切除術以上の術式 (6 例) では, 局所再発 を認めなかった。ささらに郭清されたリンパ節には転移 を認めなかったことから，標準的なりンパ節郭清は必 要ないが, 胸筋を含めた乳房切除術が局所再発を防ぐ ために必要であると報告している．

一方病理組織学的に断端に腫瘍を認めないように充 分に腫湯から距離がとれていれば広範囲の乳腺部分切 除術のみでも ${ }^{161187}$ 単純乳房切除術でも ${ }^{17}$ 局所の治療と しては充分であるとの報告もある.

乳腺の肉腫の放射線治療や化学療法は，あまり効果 がないといわれているが”，改善を示唆する報告も散 見されている ${ }^{18)}$.

ホルモン療法は, 乳腺の肉腫にはホルモンレセフ ターがなく効果がないといわれている゙. 自験例でも 脂肪芽細胞にはホルモンレセプターを認めていない.

自験例では吸引細胞診は行っていないが, 乳腺の肉 腫の術前の組織診断には, Trucut biopsy や fineneedle aspiration が乳癌と同じように施行され評価さ れている1100.

葉状腫瘍に発生した脂肪肉腫の臨床経過から，その 発生について Jimenez $z^{2 n !} ら は ，$ 線維腺腫が葉状腫湯に 変異し，それから脂肪肉腫へ悪性変異したか，はじめ から葉状腫瘍として発生 (de novo) し，それが脂肪肉 腫へ悪性変異したと推測している.

$$
\text { 結語 }
$$

触診および画像診断上，良性腫瘍との鑑別が困難で あった脂肪肉腫様の分化を示した乳腺悪性葉状腫瘍の 1 例を経験したので報告した。

謝辞：病理組織診断に関して御助言をいただいた癌研究 所乳腺病理部坂本吾偉先生に深謝致します。

\section{文载}

1) Pollard SG, Mark PV. Temple LN, et al : Breast sarcoma : A clinicopathologic review of 25 cases. Cancer 66:941-944. 1990

2）浜崎美景, 浜家一雄, 藤田 甫他: 脂肪肉腫 : 8 例の臨床病理学的研究。細胞核病理誌 $12: 73-$ 82,1968

3) 山本 浩, 藤田吉四郎, 阿部令彦他：乳腺肉腫. 日 
癌治療会誌 $5: 374,1968$

4) 佐藤栄一：脂肪肉腫の病理, 45 例の組織学的分類 と爁別診断. 莓の臨 $16: 690-705,1970$

5）小県 昇, 今居俊雄, 工藤寞昭他：乳腺脂腺脂肪肉 腫の 1 例. 日臨外医会誌 $33: 203,1972$

6) Ii K, Hizawa K. Okazaki K, et al : Liposarcome of the breast : fine structural and histochemical study of a case and review of 42 cares in the literature. Tokushima J Exp Med 27 : 45-56, 1980

7) Kanemoto K, Nakamura T, Matsuyama S. et al : Liposarcoma of the breast, review of the litera. ture and a report of a case. Jpn J Surg $11: 381-$ 384. 1981

8）白倉外茂夫, 矢嶋 嶺：乳房脂肪肉腫の 1 例. 信州 医誌 $30: 536$ - 537.1982

9）柴田紘一郎, 古賀保箷, 鬼塚敏男他：乳腺脂肪肉腫 の経験. 外科診療 $10: 1289-1292,1983$

10）井上清俊, 中谷守一, 健他：乳房脂肪肉腫の 1 例. 日癌治療会誌 $18: 1213-1214,1983$

11）高鸠成光, 吉澤順一, 平井隆二他：脂肪肉腫と思方 れる 1 症例. 日癌治療会誌 $18: 1210,1983$

12) 杉山勇治, 渡辺哲弥, 增田 浩他：巨大な乳腺脂肪
肉腫の経験。日臨外医会誌 $50 ： 1915,1989$

13）杉山和義, 河端 誠, 射場敏明他：乳腺原発脂肪肉 腫の 1 例. 日臨外医会誌 $52: 2907-2911,1991$

14）斉藤英一，四條裕正，勝浦康光他：乳腺脂肪肉腫の 1 例. 日臨外医会誌 53(增刊)：375, 1992

15）佐古田洋子, 河野範男, 寒原芳治他：乳腺脂肪肉腫 の 1 例. 日臨外医会誌 $55 ： 2517-2521,1994$

16) Austin RM. Dupree WB : Liposarcoma of the breast : A clinicopathologic study of 20 cases. Hum Pathol 17 : 906-913, 1986

17) Christensen L. Schiodt T. Blichert-Toft M, et al : Sarcomas of the breast : A clinico-pathological study of 67 patients with long term follow-up. Eur J Surg Oncol 14:241-247, 1988

18) Moore MP. Kinne DW : Breast Sarcoma. Surg Clin North Am 76:383-392, 1996

19) Fourst RL, Berry AD, Moinuddin SM : Fine needle aspiration cytology of liposarcoma of the breast. Acta Cytol 38 : 957-960, 1994

20) Jimenez JF, Gloster ES, Perrot LJ, et al : Liposarcoma arising within a cystosarcoma phyllodes. J Surg Oncol $31: 294-298,1986$

\title{
A CASE OF MALIGNANT PHYLLODES TUMOR OF THE BREAST UNDER $2 \mathrm{~cm}$ IN DIAMETER WITH LIPOSARCOMATOUS DIFFERENTIATION
}

\author{
Michihiro ORIHATA, Hiroaki MITUHASHI, Naoki NEGAMI, Makoto HATA, \\ Minoru MORIWAKI, Teruo KAKEGAWA, Gensyu TATE* \\ and Toshiyuki MITUYA* \\ Department of Surgery, Kokusaisinzen Hospital \\ - Department of Pathology. Showa University Fujigaoka Hospital
}

We have experienced a case of malignant phyllodes tumor of the breast with liposarcomatous differentiation. A 53 year-old woman was admitted to the hospital because of a painless right greast tumor. On physical examination, a $1.5 \mathrm{~cm}$ sized, clear and hard tumor was present at the lateral half of the right breast ( $\mathrm{CD}$ areas). Ultrasonography revealed a clear margin with the lateral shadow, a low ratio of length and breadth of the tumor, and a mosaic of low and high echoic pattern. With manmography, it had a clear margin and halo. From an excisional biopsy, it was diagnosed as the malignant phyllodes tumor of the breast with liposarcomatous differentiation. Modified radical mastectomy $(\mathrm{Bt}+\mathrm{Ax}$ ) was carried out. No axillary lymph node metastasis was observed. She had no radiation therapy nor chemotherapy, but she has been free from recurrence of liposarcoma one year and 10 months after the surgical teatment. 